\section{Anemia and functional capacity in elderly Brazilian hospitalized patients}

\author{
Anemia e capacidade funcional em idosos \\ brasileiros hospitalizados
} La anemia y la capacidad funcional de los ancianos
brasileños hospitalizados

\begin{abstract}
This study evaluated the association between anemia and physical functional capacity in a cross-sectional population-based sample of 709 hospitalized elderly patients aged 60 years and over admitted to the Madre Teresa Hospital, Belo Horizonte, State of Minas Gerais, Brazil. The Mann-Whitney or " $t$ " test, and chi-square or Fisher exact test were used for quantitative and categorical variables, respectively, and hierarchical binary logistic regression was used to identify significant predictors. The presence of anemia was found in $30 \%$ of participants and was significantly associated with decreased functionality according to the two measures which were used - ADL (activities of daily living) and IADL (instrumental activities of daily living). Anemia was also independently associated with older age. The results of this study demonstrate a strong association between the presence of anemia and lower levels of functional capacity. Further investigations are needed to assess the impact of anemia treatment on the functionality and independence of older people.
\end{abstract}

Anemia; Activities of Daily Living; Aged
Raquel de Macedo Bosco 1,2

Elisa Priscila Souza Assis 3

Renata Rosseti Pinheiro 3

Luiza Cristina Viana de Queiroz 3

Leani S. M. Pereira 4

Carlos Maurício Figueiredo Antunes 5

\section{Resumo}

O presente estudo avaliou a associação entre anemia e a capacidade física funcional em idosos hospitalizados. Estudo transversal, com amostra de 709 participantes com idades $\geq 60$ anos, internados no Hospital Madre Teresa, em Belo Horizonte, Minas Gerais, Brasil. Foram utilizados os testes de Mann-Whitney ou " $t$ " e quiquadrado ou teste exato de Fisher para as variáveis quantitativas e categóricas, respectivamente, e um modelo hierárquico de regressão logística foi usado para identificar as variáveis preditoras associadas. A presença de anemia foi encontrada em $30 \%$ dos participantes e associada a uma diminuição significativa da funcionalidade em ambos os índices utilizados - AVD (atividades da vida diária) e AIVD (atividades instrumentais da vida diária). A idade avançada também foi independentemente associada com anemia. Os resultados deste estudo demonstraram uma forte associação entre a redução da capacidade funcional e a presença de anemia. Investigações adicionais são necessárias para avaliar o impacto do tratamento da anemia na melhora da funcionalidade e independência em pessoas idosas.

Anemia; Atividades Cotidianas; Idoso 


\section{Introduction}

Although hemoglobin levels decrease naturally with age, anemia is not considered a natural consequence of the aging process. The main known causes of anemia are nutritional deficiency, chronic diseases and/or renal failure 1,2,3. Anemia associated with chronic inflammation plays a peculiar role among the elderly and its origin is still not clear. Studies suggest that oxidative stress that accompanies aging may be the real cause of chronic inflammation in the elderly and a major cause of anemia 4 .

Anemia is common among the elderly and its presence should always be investigated. It is estimated that one out of every seven to eight elderly people is affected by anemia and among hospitalized individuals and those in nursing homes this proportion rises significantly, often reaching $50 \%$ 5,6,7,8,9.

However, studies that have attempted to quantify anemia prevalence in this population have reported discrepant results due to the lack of standard methods and differences in the characteristics of the studied groups 8,9.

Anemia has been highlighted as one of the factors responsible for health decline amongst the elderly population, and has been associated with several symptoms (loss of muscle tone, weakness, fatigue, increase in the number of falls, loss of functional independence, cognitive alterations and depression), and a consequent rise in morbidity and general mortality, even among mild cases $3,8,10,11,12,13,14,15$.

It is estimated that by 2020 the elderly population in Brazil will reach 30 million people, representing the sixth largest elderly population in the world, and by 2050 the elderly will make up $30 \%$ of the population of the country 16 .

However, only a few Brazilian studies have investigated the prevalence of anemia in the elderly population and none of these include hospitalized patients. Furthermore, we found no studies addressing the health consequences associated with anemia 17,18,19.

The aim of the present study was to evaluate the relationship between the presence of anemia upon hospital admission and previous functional capacity, and the influence of socioeconomic and cultural differences, in a sample of Brazilian elderly patients and compare these results to those found in literature outside Brazil.

\section{Patients and methods}

\section{Studied population}

A total of 1,047 elderly ( $\geq 60$ years) inpatients attending a General Hospital in Belo Horizonte, State of Minas Gerais, Brazil were selected between June 2006 and January 2009. The sample included both Brazilian Unified National Health System (SUS) and private health patients. Patients hospitalized within the last 48 hours were randomly selected from the hospital's daily admissions list. A total of 146 patients were excluded due to hospital discharge, death or clinical instability during selection. After analyzing the remaining 901 medical records, another 105 patients were also excluded due to the following reasons: (1) presence of a chronic and severe incapacitating illness leading to total inability to carry out functional tasks (a score of 3 in three or more domains of activities of daily living - ADL); (2) diagnosis with acute or chronic bleeding; (3) diagnosis with neoplastic or chronic kidney disease; and (4) presence of severe visual and/or auditory impairments. Patients that signed an informed consent form (five refusals) underwent cognitive assessment using the Folstein MiniMental State Examination (MMSE) test with the following scores: $\leq 13$ for patients who are illiterate; $\leq 18$ for patients with one to seven years of schooling; and $\leq 26$ for patients with eight or more years of schooling) 20 .

Patients with acceptable results were interviewed by previously trained personnel using a specially designed questionnaire. A total of 82 individuals were excluded after completion of the MMSE, giving a final study sample of 709 patients (Figure 1). This investigation was approved by the Ethics Boards of the Madre Teresa Hospital and Santa Casa located in Belo Horizonte.

\section{Anemia}

Anemia was defined according to World Health Organization $(\mathrm{WHO})^{21}$ guidelines $(\mathrm{Hb}<120.0 \mathrm{~g} / \mathrm{L}$ for women, and < 130.0g/L for men). Blood samples were collected during the first 48 hours after hospitalization, and $\mathrm{Hb}$ was measured using the Beckman Coulter T890 hematology analyzer (Beckman Coulter, Miami, USA).

\section{Physical functional capacity}

Physical functional capacity was assessed by selfappraisal, considering the 30 days prior to hospitalization using the Katz index and Lawton scale which are commonly used in research with the elderly 22,23,24,25. 
Figure 1

Flowchart describing patient selection criteria.

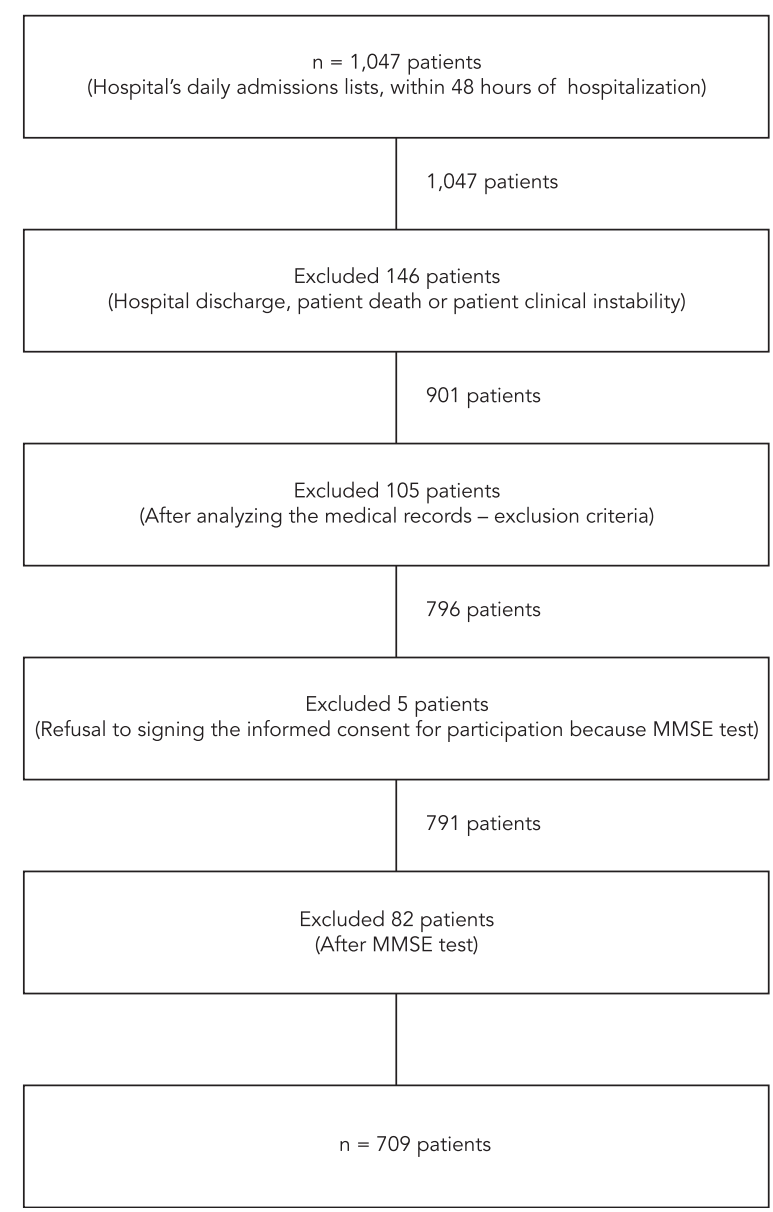

The Katz index (ADL) was applied to assess the amount of care and assistance the subjects needed to perform basic daily life activities (personal hygiene and grooming, dressing and undressing, functional transfers - getting from bed to wheelchair, getting onto or off of toilet, etc., bowel and bladder management, self-feeding) 26 The Lawton Instrumental Activities of Daily Living (IADL) Scale was used to evaluate more complex activities (ability to use the telephone, shopping, food preparation, housekeeping, laundry, means of transportation, responsibility for taking medications, ability to handle finances) 27 .

Patients were considered to have suffered a loss of functional capacity when they required help to perform any of the activities detailed by the Katz index and Lawton scale. Functional limi- tations were classified into the following categories according to the respective ADL and IADL scores: none - ADL score of 0 and IADL score of 27; moderate $-\mathrm{ADL}$ score of 3 in one to two tasks and/or an IADL score of 1 in one to four domains; and severe - ADL score of 3 in $\geq$ three tasks and/or an IADL score of 1 in $\geq$ five domains. The number of activities with functional loss, as well as the total score for each measure, was registered for all participants.

\section{Covariates}

The following sociodemographic variables were included in this study: age, gender, education, family background, former and/or current professional activity, and income. The following 
medical variables were also assessed: hospitalization type (scheduled, emergency, clinical or surgical); diagnosis; comorbidities; smoking history; number of daily prescribed medications (during the 30 days prior to hospitalization); hospitalizations in the previous year; medical complications during hospital stay; length of stay in hospital (including ICU); and mortality.

\section{Statistical analysis}

Univariate analysis was carried out to compare anemic and non-anemic groups. The "t-test" or Mann-Whitney test (Anderson-Darling to test for normality) and chi-square or Fisher's exact tests were used for quantitative and categorical variables, respectively. Hierarchical binary logistic regression models including the social demographic and medical variables were constructed to identify significant predictor variables for both the ADL and IADL. Characteristics presenting a $\mathrm{p}$-value $\leq 0.2$ from the univariate analysis were included in the initial (full) models. Those variables with a p-value $\leq 0.05$ after fitting the initial model were carried forward to the final model (backward selection). Model adjustment was evaluated using the Hosmer \& Lemeshow test. All procedures were carried out using the Epi Info version 3.5 (Centers for Disease Control and Prevention, Atlanta, USA) and SPSS version 12 (SPSS Inc., Chicago, USA) statistical packages.

\section{Results}

The mean age of the sample was $73.2 \pm 8.2$ years, $51.6 \%$ were women and 213 participants $(30 \%$, $\mathrm{n}=709$ ) had anemia. No significant gender differences were found. Mean Hb levels in anemic and non-anemic participants were $113.0 \pm 10.6$ and $138.5 \pm 10.5 \mathrm{~g} / \mathrm{L}$, respectively (Table 1 ).

Anemic patients were older, had a lower level of education level and income, were taking more medications and had a higher number of comorbidities (congestive cardiac insufficiency, arrhythmia, diabetes, peripheral vascular disease and chronic renal insufficiency). It was also found that the this group had lower cognitive performance based on the MMSE, had been hospitalized for urgent or clinical treatment more times in the previous year, and length of hospital stay, including intensive care (Table 1) was greater.

The nonanemic patients had a more active lifestyle, and were more likely to perform a professional activity and/or live alone (30.3 vs. 15.5, Table 1).

Medical complications associated to hospitalization were reported in $17.6 \%$ of participants.
Acute respiratory insufficiency (13.6 vs. 7.7) and acute renal insufficiency (4.2 vs. 1.6) were significantly higher among anemic patients. Smoking history was not a differentiating factor (Table 1).

The overall rate of mortality was $9.5 \%$ and, despite being higher in anemic patients, there was no significant difference between the two groups (6.1 vs. 3.4, Table 1).

A considerable reduction in physical functional capacity was observed in the anemic patients, both in terms of higher total scores and the number of activities with functional loss (Table 2). It is important to note, however, that the majority of participants did not present any functional decline according to the results of the Katz and Lawton measures (646/91\% and 499/71\%, respectively). In light of these results, multivariate analysis was carried out using logistic models (ADL - Katz score of $0=$ reference, score of $\geq 1=$ risk; IADL - Lawton score of $27=$ reference, score of $\leq 26$ = risk). All sociodemographic and medical variables, except hypertension and coronary heart disease, were included in the initial analysis (full models).

The results of the final logistical regression models fitted to the ADL and IADL scores are presented in Table 3. Anemic patients presented a high level of functional loss in both models: ADL (OR = 12.7; 95\%CI: 6.3-25.9); IADL (OR = 15.9; 95\%CI: 10.7-23.7). Anemia was independently associated with older age in the ADL model $(\mathrm{OR}=1.04$; 95\%CI: 1.02-1.06).

\section{Discussion}

Prevalence of anemia in the study population was $30 \%$. Other studies of the elderly in Brazil have reported anemia prevalence rates ranging from $4.3 \%$ to $31.8 \% 17,18,19$.

A systematic review conducted by Gaskell et al. 9 found that average anemia prevalence in the elderly population was $17 \%$ (varying between $3 \%$ and $50 \%$, while in four studies conducted with more than 13,000 hospitalized patients, anemia prevalence varied between $40 \%$ and $72 \%$.

The lower prevalence rate found by this study is probably due to the stringent inclusion criteria adopted, which excluded a number of potential anemic patients. It should be emphasized that our intention was not to estimate the prevalence of anemia in the study population, but rather to investigate the possible association between anemia and previous functional decline. It is also possible that the wide diversity of cultural and sociodemographic characteristics among the study population contributed to the lower prevalence rate. 
Table 1

Sociodemographic, economic and clinical characteristics of the sample.

\begin{tabular}{|c|c|c|c|}
\hline Characteristics & $\begin{array}{c}\text { Anemic } \\
(n=213)\end{array}$ & $\begin{array}{c}\text { Nonanemic } \\
(n=496)\end{array}$ & p-value \\
\hline Age (years) * $[$ mean $\pm S D]$ & $75.9 \pm 8.5$ & $72.1 \pm 7.8$ & $<0.001$ \\
\hline Female [n (\%)] & $121(56.8)$ & $245(49.4)$ & 0.07 \\
\hline \multicolumn{4}{|l|}{ Education (years) [n (\%)] } \\
\hline None/Up to 1 & $32(15.0)$ & $46(9.2)$ & \multirow{4}{*}{0.041} \\
\hline $1-7$ & $124(58.2)$ & $261(52.6)$ & \\
\hline $8-14$ & $38(17.8)$ & $111(22.4)$ & \\
\hline 15 or over & $19(8.9)$ & $78(15.7)$ & \\
\hline Living alone [n (\%)] & $19(8.9)$ & $75(15.1)$ & 0.01 \\
\hline Current professional activity [n (\%)] & $33(15.5)$ & $150(30.3)$ & $<0.001$ \\
\hline Average monthly income $(R \$){ }^{\star \star}[$ median, $25-75 \%]$ & $700.00(350-1,600)$ & $900.00(350-2,300)$ & 0.053 \\
\hline \multicolumn{4}{|l|}{ Comorbidities [n (\%)] } \\
\hline Hypertension & $161(75.6)$ & $376(75.8)$ & 0.95 \\
\hline Congestive heart failure & $63(29.6)$ & $53(10.7)$ & $<0.001$ \\
\hline Coronary heart disease & $91(42.7)$ & $211(42.5)$ & 0.96 \\
\hline Peripheral artery disease & $26(12.2)$ & $35(7.0)$ & 0.025 \\
\hline Arritmia & $47(22.0)$ & $69(13.9)$ & 0.007 \\
\hline Diabetes mellitus & $76(35.7)$ & $121(24.4)$ & 0.002 \\
\hline Chronic renal insufficiency & $26(12.2)$ & $7(1.4)$ & $<0.001$ \\
\hline Number of comorbidities [mean \pm SD] & $3.4 \pm 1.2$ & $2.6 \pm 1.1$ & $<0.001$ \\
\hline Smoker [n (\%)] & $26(12.2)$ & $53(10.79)$ & 0.142 \\
\hline \multicolumn{4}{|l|}{ Number of medications used [n (\%)] } \\
\hline $0-3$ & $74(34.7)$ & $229(46.1)$ & \multirow{3}{*}{0.038} \\
\hline $4-6$ & $94(44.1)$ & $200(40.3)$ & \\
\hline$\geq 7$ & $45(21.1)$ & $67(13.5)$ & \\
\hline Previous hospitalization [n (\%)] & $100(46.9)$ & $154(31.09)$ & $<0.001$ \\
\hline Previous hospitalization ICU [n (\%)] & $46(21.69)$ & $60(12.1)$ & $<0.001$ \\
\hline \multicolumn{4}{|l|}{ Types of hospitalization 1 [n (\%)] } \\
\hline Scheduled & $39(18.3)$ & $140(28.2)$ & \multirow{2}{*}{0.005} \\
\hline Emergency & $174(81.4)$ & $356(71.8)$ & \\
\hline \multicolumn{4}{|l|}{ Types of hospitalization 2 [n (\%)] } \\
\hline Clinical & $124(58.7)$ & $214(43.3)$ & \multirow{2}{*}{$<0.001$} \\
\hline Surgery & $89(41.3)$ & $282(56.6)$ & \\
\hline Creatinine $\mathrm{g} / \mathrm{dL}$ ** [median, $25-75 \%]$ & $1.2(0.9-1.6)$ & $1.0(0.8-1.2)$ & $<0.001$ \\
\hline MMSE score * $[$ mean \pm SD $]$ & $23.5 \pm 3.8$ & $25.1 \pm 3.6$ & $<0.001$ \\
\hline Number of days in ICU [mean \pm SD] & $4.6 \pm 6.8$ & $3.3 \pm 5.4$ & 0.0046 \\
\hline Number of days of hospitalization ** [median, 25-75\%] & $8(4-14)$ & $6(3-10)$ & $<0.001$ \\
\hline \multicolumn{4}{|l|}{ Complications [n (\%)] } \\
\hline Acute respiratory insufficiency & $29(13.6)$ & $38(7.79)$ & 0.013 \\
\hline Acute renal insufficiency & $9(4.2)$ & $8(1.69)$ & 0.037 \\
\hline Mortality [n (\%)] & $13(6.1)$ & $17(3.4)$ & 0.105 \\
\hline
\end{tabular}

ADL: activities of daily living; IADL: instrumental activities of daily living; MMSE: Mini Mental State Examination; SD: standard deviation.

Note: all percentages were calculated relative to the total population.

* $\mathrm{p}$-value based on t-test;

** $p$-value based on the Mann-Whitney non-parametric test for continuous variables and on the chi-square or Fisher's exact test for categorical variables. 


\begin{tabular}{|c|c|c|c|}
\hline \multicolumn{4}{|l|}{ Functional capacity: Katz and Lawton's measures. } \\
\hline $\begin{array}{l}\text { Functional capacity (in the } 30 \text { days prior } \\
\text { to hospitalization) }\end{array}$ & $\begin{array}{c}\text { Anemic } \\
(n=213)\end{array}$ & $\begin{array}{l}\text { Non anemic } \\
(n=496)\end{array}$ & p-value * \\
\hline \multicolumn{4}{|l|}{ Katz (ADL) } \\
\hline Total score $[$ mean $\pm \mathrm{SD}]$ & $0.7 \pm 1.5$ & $0.04 \pm 0.4$ & $<0.001$ \\
\hline Number of disabilities, [mean $\pm \mathrm{SD}]$ & $0.5 \pm 1.0$ & $0.03 \pm 0.3$ & $<0.001$ \\
\hline Bathing [\%] & 22.5 & 1.2 & $<0.001$ \\
\hline Dressing [\%] & 18.3 & 0.4 & $<0.001$ \\
\hline Going to the toilet [\%] & 3.3 & 0.2 & 0.001 \\
\hline Transfer [\%] & 5.2 & 0.4 & $<0.001$ \\
\hline Continence [\%] & 5.2 & 0.8 & $<0.001$ \\
\hline Feeding [\%] & 0.0 & 0.0 & $<0.001$ \\
\hline \multicolumn{4}{|l|}{ Lawton (IADL) } \\
\hline Total score $[$ mean $\pm \mathrm{SD}]$ & $23.1 \pm 3.5$ & $26.4 \pm 1.9$ & $<0.001$ \\
\hline Number of disabilities [mean \pm SD] & $3.3 \pm 2.7$ & $0.4 \pm 1.4$ & $<0.001$ \\
\hline Ability to use the telephone [\%] & 8.9 & 0.8 & $<0.001$ \\
\hline Transportation [\%] & 47.0 & 8.9 & $<0.001$ \\
\hline Shopping [\%] & 55.4 & 8.7 & $<0.001$ \\
\hline Food preparation [\%] & 32.9 & 3.8 & $<0.001$ \\
\hline Housekeeping [\%] & 56.8 & 7.9 & $<0.001$ \\
\hline Hand works [\%] & 11.7 & 1.2 & $<0.001$ \\
\hline Laundry [\%] & 54.5 & 6.8 & $<0.001$ \\
\hline Responsibility for own medications [\%] & 31.0 & 3.2 & $<0.001$ \\
\hline Ability to handle finances [\%] & 29.6 & 3.2 & $<0.001$ \\
\hline
\end{tabular}

ADL: activities of daily living; IADL: instrumental activities of daily living; SD: standard deviation.

Note: all percentages were calculated relative to the total population.

* $p$-values are based on the Mann-Whitney non-parametric test for continuous variables and on the chi-square or Fischer's exact test for categorical variables.

Table 3

Variables associated with anemia after multivariate analysis - final models.

\begin{tabular}{lcc}
\hline Variables & Katz (ADL) model \\
OR $(95 \% \mathrm{Cl})$ & Lawton (IADL) model \\
OR $(95 \% \mathrm{Cl})$
\end{tabular}

ADL: activities of daily living; IADL: instrumental activities of daily living; OR: odds ratio; 95\%Cl: $95 \%$ confidence interval.

* Hosmer \& Lemershow test.

The results show that older individuals are more likely to develop anemia. This finding corroborates the findings of the majority of studies which demonstrate that prevalence of anemia increases proportionately with age 8,9,14,28,29,30.
This study also shows that there is a direct association between aging and a decrease in functional capacity. On average, the likelihood of a decline in functional performance is 1.06 times (ADL) and 1.11 times (IADL) greater for each ad- 
ditional year of life; thus, with a five-year increase in age the likelihood is 5.30 and 5.55 times greater, respectively. The association between aging and functional decline is a common finding in the literature $31,32,33,34,35,36$.

Although some studies observed gender differences in anemia prevalence $3,37,38$, no significant gender differences were observed by this study. However, it interesting to note that women were twice as vulnerable to a decline in functional performance than men, corroborating the results of other studies. Although females have a greater life expectancy, the proportion of years lived without disability is smaller than in males $39,40,41$.

The results also show a strong association between anemia and physical functional loss in the models tested: patients with anemia on admission to hospital were 12.7 (ADL) or 15.9 (IADL) times more likely to have low physical functional capacity during the 30 days prior to admission. This decline in functionality of the elderly was observed both in terms of the total score and the number of compromised activities. This is the first study to address the association between anemia and decreased physical functional capacity among a sample of the Brazilian population. The results of this study are similar to the findings of studies undertaken outside Brazil which evaluated anemia and functional capacity among the elderly 8,9,14,42,43,44.

Studies have reported hemoglobin values similar the findings of our study $(>10 \mathrm{~g} / \mathrm{dL}$ ) suggesting that anemia in the elderly generally tends to be mild $29,45,46$.

There is currently a debate about a possible change in the hemoglobin threshold level recommended by WHO for the diagnosis of anemia, with some authors claiming that small reductions in hemoglobin are a normal consequence of aging $38,47,48$. However, several studies have shown that even mild anemia in the elderly is associated with several deleterious effects on the health, including increased morbidity and mortality. Therefore, even mild anemia should be considered a warning sign of possible health problems, including serious underlying disease $3,10,22,49,50$. In line with this, our study shows that, despite mean hemoglobin levels slightly below those recommended by WHO 21, a number of negative health consequences were observed in anemic elderly patients, even those with mild anemia 3,22 .

Regarding family arrangements, our results showed that a higher proportion of anemic elderly patients lived with a family member than non anemic patients. On the other hand, a significantly higher proportion of nonanemic patients reported living alone. Furthermore, elderly people living alone showed a lower level of func- tional capacity loss than those living with family members $32,33,34,51$. This is probably because it is necessary to be functionally active to perform essential daily tasks and activities.

It has been shown that a large proportion of Brazilian elderly live in multigenerational residential arrangements, especially those with low income and low socioeconomic status. In contrast, those living in better socioeconomic conditions are more likely to live alone or with a partner, following the pattern observed in more developed countries 31 .

It is possible that elderly people living with their families are more vulnerable to health conditions that compromise their independence, whereas those living alone experience better health and are more independent with respect to self-care and social relations. However, due to the cross-sectional design of this study, a causal pathway cannot be established.

With regard to occupation, our results show that roughly a quarter of the sample was engaged in a regular professional activity and that this proportion was higher among nonanemic patients. Although no association between professional activity and anemia or functional capacity was identified, it is plausible that regular professional activity requires good health.

No significant association was found between income, education level and anemia, corroborating other studies $3,22,52$.

The rate of hospitalization in the year preceding the study was higher among anemic patients and the results of the multivariate analysis showed that the likelihood of disability in individuals that reported previous hospitalization was twice as great. These results are consistent with the findings of other studies 13,14,53. The presence of chronic diseases and comorbidities, usually long term illnesses, is frequent in this population, increasing the probability of clinical instability and the need of frequent hospitalization and repeated hospitalization may be used as an estimate of frailty in this group 54 .

Regarding cognitive capacity, the performance of anemic patients in the MMSE test was worse, and patients with lower levels of physical functional capacity also obtained generally low scores confirming associations between cognitive impairment, anemia and functional capacity already reported in the literature $35,55,56,57,58$.

The overall rate of mortality was $9.5 \%$; the rate was higher among anemic patients but this difference was not significant. This result contrasts with the findings of other studies 3,14,30,46,59; however, it should be noted that participants were not followed up after the hospital stay. 
The autonomy of elderly people, in terms of self-care and living environment, is directly related to functional capacity. Disability cannot be considered a static situation, but rather a dynamic and complex process that involves a number of individual and environmental factors.

The association between anemia and decreased physical functional capacity is well documented in the literature 8,9,10,13,22,58. The signs and symptoms associated with anemia in the elderly vary according to several factors, including anemia duration. In chronic anemia, spontaneous complaints of older patients are generally less common. Often without realizing it, the elderly progressively decrease levels of physical activity until it becomes asymptomatic.

A decrease in hemoglobin levels, with a consequent decrease in the number of red blood cells, causes a reduction in the flow of oxygen in all organs, which has clinical manifestations. These symptoms increase with physical activity, which requires a greater oxygen supply 60 . As a consequence, the elderly progressively reduce their routine activities leading to a progressive level of functional dependency.

Although it is still not clear whether active interventions for the treatment of anemia are beneficial to all older people, many studies have shown the clear benefits of early diagnosis and treatment of anemia for various diseases, such as congestive heart failure 61,62 and chronic kidney disease 63 , with significant improvements in functional capacity, cognitive functions and quality of life.

The cross-sectional nature of our study can be considered a limitation, since it was not possible to determine the temporal relations between the variables. Furthermore, the fact that information concerning functionality was self-reported may have resulted in errors when qualifying disability.

\section{Conclusion}

Anemia is recognized as a significantly independent predictor for morbidity, frailty and functional loss in the elderly, and is potentially modifiable. The results of this study of a sample of Brazilian hospitalized elderly showed that there was an association between the presence of anemia and reduced functional capacity. Since the measurement of hemoglobin levels is routine with hospitalized elderly and in outpatient services, the presence of anemia may be used as an important marker of the risk of functional decline. Further research is still needed to evaluate improvements in functionality and independence in the elderly as a result of anemia treatment.

\section{Resumen}

Este estudio evaluó la asociación entre la anemia y la capacidad física funcional en ancianos hospitalizados. Se trató de un estudio transversal con una muestra de 709 participantes con edad $\geq 60$ años, ingresados en el hospital Madre Teresa, Belo Horizonte, Minas Gerais, Brasil. Se aplicó el Mann-Whitney o "t" y chi-cuadrado o la prueba exacta de Fisher para las variables cuantitativas y categóricas, respectivamente, así como un modelo jerárquico binario de regresión logística para identificar predictores significativos. La presencia de anemia se encontró en un $30 \%$ de los participantes y se asoció con una disminución significativa de la funcio- nalidad en ambos indices utilizados - AVD (actividades de la vida diaria) y de AIVD (actividades instrumentales de la vida diaria). La edad avanzada también se asocia de forma independiente con la anemia. Los resultados de este estudio demostraron una fuerte asociación entre una menor capacidad funcional y la presencia de anemia. Se necesitan más investigaciones para evaluar los efectos del tratamiento de la anemia en la mejora de la funcionalidad y la independencia de los ancianos.

Anemia; Actividades Cotidianas; Anciano 


\section{Contributors}

R. M. Bosco, L. S. M. Pereira and C. M. F. Antunes participated in project conception, data interpretation, drafting and approval of the final version of this article. E. P. S. Assis participated in data collection and drafting and approval of the final version of this article. R. R. Pinheiro and L. C. V. Queiroz contributed to data analysis and interpretation and drafting of this article.

\section{References}

1. Ania BJ, Suman VJ, Fairbanks VF, Rademacher DM Melton LJ. Incidence of anemia in older people: an epidemiologic study in a well defined population. J Am Geriatr Soc 1997; 45:825-31.

2. Lipschitz D. Medical and functional consequences of anemia in the elderly. J Am Geriatr Soc 2003; 51 Suppl:S10-3.

3. Chalmers KA, Knuiman MW, Divitini ML, Bruce DG, Olynyk JK, Milward EA. Long-term mortality risks associated with mild anaemia in older persons: the Busselton Health Study. Age Ageing 2012 41:759-64.

4. Macciò A, Madeddu C. Management of anemia of inflammation in the elderly. Anemia 2012 2012:563251.

5. Bose SK, Andrews J, Roberts PD. Haematological problems in a geriatric unit with special reference to anaemia. Gerontol Clin (Basel) 1970; 12: 339-46.

6. Bird T, Hall MR, Schade RO. Gastric histology and its relation to anaemia in the elderly. Gerontology 1977; 23:309-21.
7. Joosten E, Pelemans W, Hiele M, Noyen J, Verhaeghe R, Boogaerts MA. Prevalence and causes of anaemia in geriatric hospitalized population. Gerontology 1992; 38:111-7.

8. Beghé C, Wilson A, Ershler WB. Prevalence and outcomes of anemia in geriatrics: a systematic review of the literature. Am J Med 2004; 116 Suppl 7A:3S-10S.

9. Gaskell H, Derry S, Moore RA, McQuay HJ. Prevalence of anaemia in older persons: systematic review. BMC Geriatrics 2008; 8:1.

10. Chaves PH, Ashar B, Guralnik JM, Friedl LP. Looking at the relationship between hemoglobin concentration and prevalent mobility difficulty in older women. Should the criteria currently used to define anemia in older people be reevaluated? J Am Geriatr Soc 2002; 50:1257-64.

11. Lipschitz D. Medical and functional consequences of anemia in the elderly. J Am Geriatr Soc 2003; 51(3 Suppl):S10-3. 
12. Cesari M, Penninx BW, Lauretani F, Russo CR, Carter C, Bandinelli S, et al. Hemoglobin levels and skeletal muscle: results from the InCHIANTI study. J Gerontol A Biol Sci Med Sci 2004; 59:249-54.

13. Penninx BW, Pahor M, Cesari M, Corsi AM. Anemia is associated with disability and decreased physical performance and muscle strengh in the elderly. J Am Geriatr Soc 2004; 52:719-24.

14. Denny SD, Kuchibhatla MN, Cohen HJ. Impact of anemia on mortality, cognition, and function in community-dwelling elderly. Am J Med 2006; 119:327-34.

15. Chaves PHM, Carlson MC, Ferrucci L, Guralnik JM, Semba R, Fried LP. Association between mild anemia and executive function impairment in community-dwelling older women: the Women's Health and Aging Study II. J Am Geriatr Soc 2006; 54:1429-35.

16. Instituto Brasileiro de Geografia e Estatística. Educação melhora, mas ainda apresenta desafios. http://ibge.gov.br/home/presidencia/noticias/ noticia_visualiza.php?id_noticia $=1233 \& i d$ _ pagina $=1$ (accessed on 27/Sep/2008).

17. Barbosa DL, Arruda IKG, Diniz AS. Prevalência e caracterização da anemia em idosos do Programa de Saúde da Família. Rev Bras Hematol Hemoter 2006; 28:288-92.

18. Schaan MD'A, Schwanke CHA, Bauer M, Luz C, Mangani I, Cruz IM, et al. Hematological and nutritional parameters in apparently healthy elderly individuals. Rev Bras Hematol Hemoter 2007; 29:136-43.

19. Colares FC, Silveira SRP, Silva APR, Córdova COA, Karnikowski MGO, Nóbrega OT. Ferro, folato e vitamina B12: análise da ingestão e ocorrência de anemia em idosas. J Bras Med 2008; 94:46-50.

20. Bertolucci PH, Brucki SM, Campacci SR, Juliano Y. O Mini-Exame do Estado Mental em uma população geral: impacto da escolaridade. Arq Neuropsiquiatr 1994; 52:1-7.

21. World Health Organization. Nutritional anaemias. Geneva: World Health Organization; 1968. (Technical Report Series, 405).

22. Maraldi C, Volpato S, Cesari M, Cavalieri M, Onder G, Mangani I, et al. Anemia and recovery from disability in actives of daily living in hospitalized older persons. J Am Geriatr Soc 2006; 54:632-6.

23. Ozaki A, Uchiyama M, Tagaya H, Ohida T, Ogihara R. The Japanese Centenarian Study: autonomy was associated with health practices as well as physical status. J Am Geriatr Soc 2007; 55:95-101.

24. Szanton LS, Thorpe RJ, Boyd C, Tanner EK, Leff $\mathrm{B}$, Agree E, et al. Community aging in place, advancing better living for elders: a bio-behavioralenvironmental intervention to improve function and health-related quality of life in disabled older adults. J Am Geriatr Soc 2011; 59:2314-20.

25. Dennis RA, Johnson LE, Roberson PK, Heif M, Boop MM, Garner KK, et al. Changes in activies daily living, nutrient intake, and systemic inflammation in elderly adults receiving recuperative care. J Am Geriatr Soc 2012; 60:2246-53.

26. Katz S, Ford AB, Moskowitz RW, Jackson BA, Jaffe MW. Studies of ilness in the aged. The index of ADL: a standardized measure of biological and psychosocial function. JAMA 1963; 85:914-9.
27. Lawton MP, Brody EM. Assessment of older people: self-maintaining and instrumental activities of daily living. Gerontologist 1969; 9:179.

28. Timiras ML, Browstein H. Prevalence of anemia and correlation of hemoglobin with age in a geriatric screening clinic population. J Am Geriatr Soc 1987; 35:639-43.

29. Guralnik JM, Eisenstaedt RS, Ferrucci L, Klein HG, Woodman RC. Prevalence of anemia in persons 65 years and older in the United States: evidence for a high rate of unexplained anemia. Blood 2004; 104:2263-8.

30. Culleton BF, Manns BF, Zhang J, Tonelli M, Klarenbach S, Hemmelgarn BR. Impact of anemia on hospitalization and mortality in older adults. Blood 2006; 107:3841-6.

31. Ramos LR. Fatores determinantes do envelhecimento saudável em idosos residentes em centro urbano: Projeto Epidoso, São Paulo. Cad Saúde Pública 2003; 19:793-8.

32. Rosa TEC, Benício MHD'A, Latorre MRDO, Ramos LR. Fatores determinantes da capacidade funcional entre idosos. Rev Saúde Pública 2003; 37:40-8.

33. Ng TP, Niti M, Chiam PC, Kua EH. Prevalence and correlates of functional disability in multiethnic elderly singaporeans. J Am Geriatr Soc 2006 54:21-9.

34. Gill TM, Allore HG, Hardy SE, Guo ZG. The dynamic nature of mobility in older persons. J Am Geriatr Soc 2006; 54:248-54.

35. Inzitari M, Di Carlo A, Marzia B, Pracucci G, Maggi S, Gandolfo C, et al. Risk and predictors of motorperformance decline in a normally functioning population-based sample of elderly subjects: the Italian longitudinal study on aging. J Am Geriatr Soc 2006 ; 54:318-24.

36. Giacomin KC, Peixoto SV, Uchoa E, Lima-Costa MF. Estudo de base populacional dos fatores associados à incapacidade funcional entre idosos na Região Metropolitana de Belo Horizonte, Minas Gerais, Brasil. Cad Saúde Pública 2008; 24:1260-70.

37. Dallman PR, Yip R, Johnson C. Prevalence and causes of anemia in the United States, 1976 to 1980. Am J Clin Nutr 1984; 39:437-45

38. Nilsson-Ehle H, Jagenburg R, Landahl S, Svanborg A. Blood haemoglobin declines in the elderly: implications for reference interval from age 70 to 88 . Eur J Haematol 2000; 65:297-305.

39. Leveille SG, Penninx BW, Melzer D, Izmirlian G, Guralnik JM. Sex differences in the prevalence of mobility disability in old age: the dynamics of incidence, recovery, and mortality. J Gerontol B Psychol Sci Soc 2000; 55:S41-50.

40. Dunlop DD, Manheim LM, Sohn MW, Liu X, Chang RW. Incidence of functional limitation in older adults: the impact of gender, race, and chronic conditions. Arch Phys Med Rehabil 2002; 83:964-71.

41. Murtagh KN, Hubert HB. Gender differences in physical disability among an elderly cohort. Am J Public Health 2004; 94:1406-11.

42. Cella D. The Functional Assessment of Cancer Therapy-Anemia (FACT-An) Scale: a new tool for the assessment of outcomes in cancer anemia and fatigue. Semin Haematol 1997; 34(3 Suppl 2):9-13 
43. Kamenetz Y, Beloosseky Y, Zelzer C, Gotlieb D Magazanik A, Fishman P, et al. Relationship between routine hematological parameters, serum IL-3,IL-6 and erythropoietin and mild anemia and degree of function in the elderly. Aging Clin Exp Res 1998; 10:32-8.

44. Chaves PH, Xue QL, Guralnik JM, Ferrucci L, Volpato S, Fried LP, et al. What constitutes normal hemoglobin concentration in community-dwelling disabled older women? J Am Geriatr Soc 2004; 52:1811-6.

45. Artz AS, Fergusson D, Drinka PJ, Gerald M, Bidenbender R, Lechich A, et al. Mechanisms of unexplained anemia in the nursing home. J Am Geriatr Soc 2004; 52:423-7.

46. Zakai NA, Katz R, Hirsch C, Shlipak MG, Chaves $\mathrm{PH}$, Newman AB, et al. A prospective study of anemia status, hemoglobin concentration, and mortality in an elderly cohort: the Cardiovascular Health Study. Arch Intern Med 2005; 165:2214-20.

47. Nilsson-Ehle H, Jagenburg R, Landahl S, Svanborg A, Westin J. Decline of blood haemoglobin in the aged: a longitudinal study of an urban Swedish population from age 70 to 81 . Br J Haematol 1989; 71:437-42.

48. Beutler E, Waalen J. The definition of anemia: what is the lower limit of normal of the blood hemoglobin concentration? Blood 2006; 107:1747-50.

49. Balducci L. Epidemiology of anemia in the elderly: information on diagnostic evaluation. J Am Geriatr Soc 2003; 51(3 Suppl):S2-9

50. den Elzen WP, Willems JM, Westendorp RG, de Craen AJ, Assendelft WJ, Gussekloo J. Effect of anemia and comorbidity on functional status and mortality in old age: results from the Leiden 85plus Study. CMAJ 2009; 181:151-7.

51. Hebert R, Brayne C, Spiegelhalter D. Factors associated with functional decline and improvement in a very elderly community-dwelling population. Am J Epidemiol 1999; 150:501-10.

52. Penninx BW, Guralnik JM, Onder G, Ferrucci L, Wallace RB, Pahor M. Anemia and decline in physical performance among older persons. Am J Med 2003; 115:104-10

53. Penninx BW, Pahor M, Woodman RC, Guralnik JM Anemia in old age is associated with increased mortality and hospitalization. J Gerontol A Biol Sci Med Soc 2006; 61:474-9.

54. Veras R. Em busca de uma assistência adequada à saúde do idoso: revisão da literatura e aplicação de um instrumento de detecção precoce e de previsibilidade de agravos. Cad Saúde Pública 2003, 19:705-15.
55. Beard CM, Kokmen E, O’Brien PC, Anía BJ, Melton LJ. Risk of Alzheimer's disease among elderly patients with anemia: population-based investigations in Olmsted county, Minnesota. Ann Epidemiol 1997; 7:219-24.

56. Baron-Epel O, Kaplan G. General subjective health status or age-related subjective health status does it make a difference? Soc Sci Med 2001; 53:137381.

57. Atti AR, Palmer K, Volpato S, Zuliani G, Winblad D, Fratiglioni L. Anemia increases the risk of dementia in cognitively intact elderly. Neurobiol Aging 2006; 27:278-84.

58. Lucca U, Tettamanti M, Mosconi P, Apolone G Gandini F, Nobili A, et al. Association of mild anemia with cognitive, functional, mood and quality of life outcomes in the elderly: the "Health and Anemia” Study. PLos ONE 2008; 3:e1920.

59. Ezekowitz JA, McAlister FA, Armstrong PW. Anemia is common in heart failure and is associated with poor outcomes: insights from a cohort of 12,065 patients with new-onset heart failure. Circulation 2003; 107:223-5.

60. Macedo MP. Envelhecimento e parâmetros hematológicos. In: Freitas EV, Cançado FAX, Neri AL, Py L, Gorzoni ML, Rocha SM, organizadores. Tratado de geriatria e gerontologia. Rio de Janeiro: Editora Guanagara Koogan; 2002. p. 699-707.

61. Horwich TB, Fonarow GC, Hamilton MA, MacLellan WR, Borenstein J. Anemia is associated with worse symptoms, greater impairment in functional capacity and a significant increase in mortality in patients with advanced heart failure. J Am Coll Cardiol 2002; 39:1780-6.

62. Kosiborod M, Smith GL, Radford MJ, Foody JM, Krumholz HM. The prognostic importance of anemia in patients with heart failure. Am J Med 2003; 114:112-9.

63. Hayashi T, Suzuki A, Shoji T, Togawa M, Okada N, Tsubakihara Y, et al. Cardiovascular effect of normalizing the hematocrit level during erythropoietin therapy in predialysis patients with chronic renal failure. Am J Kidney Dis 2000; 35:250-6.

Submitted on 16/Oct/2012

Final version resubmitted on 29/Jan/2013

Approved on 18/Feb/2013 